\author{
Marcin Drewek \\ Uniwersytet Mikołaja Kopernika, Toruń \\ drewek@umk.pl
}

\title{
Kwestia ważności testamentu w prawie amerykańskim na przykładzie prawa stanu Teksas
}

DOI: http://dx.doi.org/10.12775/SIT.2017.006

W obecnym polskim obrocie prawnym daje się coraz częściej dostrzec dążenie osób fizycznych do przekazania przyszłym spadkobiercom wypracowanego przez siebie majątku zgodnie ze swoją wolą, zamiast pozostawiania tej kwestii wyłącznie woli ustawodawcy (dziedziczeniu ustawowemu). W związku z tym wzrasta systematycznie znaczenie testamentów, za pomocą których testator może rozrządzić majątkiem na wypadek śmierci, zgodnie ze swoją wolą.

Pojawia się kwestia, co w sytuacji, gdy testament nie będzie stanowił wiernego odwzorowania woli testatora. W takim wypadku mówić można o wadliwości testamentu. Zadaniem ustawodawcy powinno być więc skonstruowanie odpowiedniego katalogu przesłanek ważności testamentu, który pozwalałby na ochronę interesu prawnego testatora, zwłaszcza swobody testowania. Wskazany katalog powinien uwzględniać także interes przyszłych spadkobierców, a także określać sankcję zaistnienia określonej wadliwości (jej wpływ na skuteczność rozrządzeń testamentowych).

W celu poszukiwania optymalnego katalogu przesłanek warunkujących ważność testamentu na gruncie prawa polskiego warto zaczerpnąć $\mathrm{z}$ bogatego dorobku systemu common law, w tym prawa amerykańskiego. Przemawiają za tym w szczególności dwa argu- 
menty. Po pierwsze, podstawowym, powszechnym i stosowanym od dawna sposobem przejścia majątku spadkowego w Stanach Zjednoczonych było i jest dziedziczenie na mocy testamentu. Dziedziczenie ustawowe jest zdecydowanie rzadsze. Stąd dorobek związany z wypracowanymi rozwiązaniami prawnym odnoszącymi się wadliwości testamentu jest bardzo bogaty. Po drugie zaś, z racji postępującej globalizacji można zauważyć coraz częstszą potrzebę stosowania do jednej sprawy spadkowej kilku systemów prawnych (przykładowo obywatel amerykański posiadający ruchomości i nieruchomości zlokalizowane na terenie Rzeczpospolitej Polskiej). Powoduje to z jednej strony konieczność znajomości i stosowania przez sądy prawa obcego, a $z$ drugiej wskazuje na przydatność harmonizacji istniejących porządków prawnych.

Celem niniejszego artykułu będzie więc przybliżenie podstawowych rozwiązań jurydycznych w zakresie kwestii przesłanek warunkujących ważność testamentu w prawie amerykańskim. Ze względu na różnorodność prawa amerykańskiego (zdeterminowanego prawem poszczególnych stanów) dalsze rozważania dotyczyć będą prawa spadkowego stanu Teksas. Jest to drugi co do wielkości (po Alasce) stan, posiada skodyfikowane prawo spadkowe, a ponadto obowiązujące na jego terenie prawo jest bardziej zbliżone do regulacji prawa civil law (z racji uwarunkowań historycznych) niż w innych stanach.

\section{Uwagi wstępne}

Na wstępie należy wskazać, że zasadnicze uregulowania prawne odnoszące się do kwestii ważności testamentu w prawie spadkowym stanu Teksas zostały uregulowane w ustawie kodeksowej Texas Probate Code ${ }^{1}$ (dalej t.p.c.), w rozdziale IV „Sporządzenie i odwołanie testamentu” (Chapter IV. „Execution and Revocation of Wills”). Przy czym spora część uregulowań prawnych zawarta jest także w orzecznictwie, co wynika ze specyfiki systemu prawa common law.

${ }^{1}$ Ustawa Texas Probate Code z 1955 r., ze zm., weszła w życie 1.01.1956 r. 
W ostatnich latach miała miejsce istotna nowelizacja prawa spadkowego Teksasu. W jej wyniku doszło do uchylenia t.p.c. i zastąpienia jej przez ustawę kodeksową Texas Estate Code ${ }^{2}$. Zdecydowana większość testamentów znajdujących się obecnie w obrocie prawnym była sporządzona zgodnie $z$ wymogami ważności przewidzianymi w treści ustawy t.p.c. (Texas Estate Code obowiązuje bowiem dopiero nieco ponad 2 lata) ${ }^{3}$. W związku $z$ tym, ze względu na dominujące znaczenie t.p.c. dla obrotu, dalsze rozważania odnoszące się do kwestii ważności testamentu dotyczyć będą właśnie tej ustawy ${ }^{4}$.

W doktrynie prawa spadkowego stanu Teksas wskazuje się, że prawa podmiotowe po śmierci mogą przejść na spadkobierców na dwa sposoby. Po pierwsze: w trybie przewidzianym przez przepisy prawa tzw. intestate (dziedziczenie nietestamentowe, które w pewnym uproszczeniu odpowiada polskiemu dziedziczeniu ustawowemu) lub po drugie: zgodnie $z$ treścią sporządzonego przez spadkobiercę testamentu, tzw. testate (w pewnym uproszczeniu dziedziczenie testamentowe). Przy czym pierwszeństwo ma dziedziczenie testamentowe. Intestate stosuje się więc co do zasady wówczas, gdy nie został sporządzony ważny testament ${ }^{5}$.

Warto dodać, że w amerykańskim prawie spadkowym przyjmuje się, iż osobie fizycznej nie przysługuje per se prawo podmiotowe do sporządzenia testamentu i decydowania o sposobie przejścia aktywów na spadkobierców po jej śmierci. Zasada ta została wyraźnie potwierdzona w jednym $z$ orzeczeń Supreme Court of the United States (Sądu Najwyższego Stanów Zjednoczonych),

2 Ustawa Texas Estate Code z 2013 r., weszła w życie 1.01.2014 r.

3 Szerzej na ten temat zob. np. G. W. Beyer, Texas Probate Code with Commentary, Lubbock 2013, s. 1; W. D. Pargaman, The Story of the Texas Estates Code, Austin 2014, s. 1.

4 Por. sec. 2 subsec. a) i b) Texas Probate Code oraz sec. 21.001. Texas Estate Code.

5 Por. np.: G. W. Beyer, Texas Probate Code, s. 41-42; S. R. Akers, Wills Road Map: Practical Considerations in Will Drafting, Austin 2012, wersja elektroniczna; N. C. Koehler (The Texas Young Lawyers Association Texas Probate Passport Team), Texas Probate Passport, Austin 2011, s. 3

6 Por. Irving Trust Co. v. Day, 314 U.S. 556, 562 (US Supreme Court 1942). 
w którym wskazano, że prawo do określenia kto ma dziedziczyć po osobie zmarłej, może wynikać jedynie z przepisów ustawy. W treści omawianego orzeczenia podniesiono także, iż wykładnia przepisów konstytucji USA wskazuje, że każdy ze stanów, w zakresie swojej kognicji, może samodzielnie unormować kwestię dziedziczenia, w tym dopuszczalność sporządzania przez obywateli testamentów ${ }^{7}$.

Ustawodawca stanu Teksas zdecydował się na przyznanie swoim obywatelom prawa podmiotowego do sporządzenia testamentu i określenia tą drogą sposobu przejścia praw po śmierci testatora na osoby wskazane w testamencie. $Z$ uwagi na wskazany wcześniej fakt, że prawo do sporządzenia testamentu w prawie amerykańskim traktowane jest jako wyjątek od zasady, sporządzony przez spadkobiercę testament nie będzie skuteczny, jeśli nie będzie spełniał wszystkich wskazanych przez przepisy prawa wymogów, i to zasadniczo w sposób ścisły. Zasada ta odnosi się więc również do prawa spadkowego obowiązującego w Teksasie ${ }^{8}$.

Niektóre ustawodawstwa stanowe przewidują dodatkowo tzw. compliance rule (w uproszczeniu: zasadę zapewnienia zgodności). Zmniejsza ona w pewien sposób rygor ścisłego przestrzegania przesłanek (zwłaszcza formalnych), które musi spełnić testament, by był ważny. W szczególności, zasada ta przyznaje sądom prawo do pominięcia drobnych wad formalnych, jeśli z całokształtu okoliczności faktycznych sprawy wyraźnie wynika, że wolą testatora było, by dany dokument został uznany za sporządzony przez niego testament. Niekiedy ustawodawstwa stanowe przewidują również tzw. savings statute (w uproszczeniu: ustawa ratująca), które również mają na celu pomoc w utrzymaniu ważności testamentu. W treści takiej ustawy znaleźć można przepisy, że nawet jeśli testament nie spełnia niektórych przesłanek niezbędnych dla jego ważności, to nadal może wywołać on niektóre skutki prawne, jeśli zaistnieją odpowiednie okoliczności stanu faktycznego. Prawo spadkowe stanu Teksas nie przewiduje wyraźnie żadnego ze wskazanych rozwiązań. Więc co do zasady wykładnia testamentu z punktu widzenia

Ibidem.

${ }^{8}$ Szerzej na ten temat por. In re Estate of Iversen, 150 S.W.3d 824 (Tex. App.-Fort Worth 2004, no pet.). 
spełnienia przez niego przesłanek warunkujących jego ważność powinna być dokonywana w sposób ścisły ${ }^{9}$.

W doktrynie prawa spadkowego Teksasu przyjmuje się cztery podstawowe przesłanki, które muszą być spełnione, by testament mógł zostać uznany za ważny i by mógł wywołać zamierzone skutki prawne. Wśród wskazanych przesłanek wyróżnić można trzy przesłanki materialnoprawne oraz jedną (choć złożoną) przesłankę formalnoprawną. Do przesłanek materialnoprawnych należą: legal capacity (odpowiada zdolności prawnej), testamentary capacity (odpowiada zdolności testamentowej) oraz testamentary intent (odpowiada woli testowania). $Z$ kolei przesłankę formalną tzw. formalities stanowią poszczególne wymogi prawe przewidziane dla określonej formy testamentu np. attested will lub holographic will. W celu określenia ważności testamentu należy zbadać, czy wszystkie cztery przesłanki zostały spełnione w sposób kumulatywny ${ }^{10}$.

W teksaskim prawie spadkowym występują ponadto przesłanki dodatkowe, których spełnienie również może mieć wpływ na ważność testamentu. Nie są one jednak przesłankami ważności testamentu sensu stricto. Chodzi tu o przesłanki warunkujące ważność zasadniczo każdej czynności prawnej. Jako przykład wskazać można błąd lub groźbę ${ }^{11}$. Ich rozważenie jest więc celowe dla określenia pełnego zakresu skuteczności sporządzonego testamentu. Warto także dodać, co oczywiste, że dla ważności testamentu niezbędne jest, by $z$ treści testamentu wynikało, kto jest testatorem ${ }^{12}$.

\section{Przesłanka legal capacity i testamentary capacity}

Odnośnie do kwestii przesłanki zdolności prawnej (legal capacity) i zdolności testamentowej (testamentary capacity) prawo spadkowe stanu Teksas wymaga, by dla ważności testamentu obie te prze-

\footnotetext{
9 Zob. np. G. W. Beyer, Texas Probate Code, s. 42.

10 Ibidem.

11 Zob. np. N. C. Koehler, op.cit., s. 6.

12 Zob. S. R. Akers, op.cit., s. 4.
} 
słanki spełnione były łącznie. Legal capacity w omawianym zakresie przysługuje osobom fizycznym, które spełniają przynajmniej jedno z następujących kryteriów. Po pierwsze, ukończyły 18 rok życia. Po drugie, pozostają lub pozostawały w związku małżeńskim. Po trzecie, w momencie sporządzania testamentu służyły w Siłach Zbrojnych Stanów Zjednoczonych Ameryki lub auxiliaries (siłach wspierających Siły Zbrojne) lub też służyły w służbach morskich. Jeśli spełnione jest przynajmniej jedno $z$ wskazanych kryteriów, osoba fizyczna posiada zdolność prawną do sporządzenia testamentu (sec. 57 t.p.c.) ${ }^{13}$. Kwestia oceny zdolności prawnej w analizowanym zakresie nie nastręcza więc większych wątpliwości interpretacyjnych.

Nieco odmienna sytuacja ma miejsce, jeśli chodzi o przesłankę zdolności testamentowej. Odnosi się ona do oceny subiektywnej kwestii, czy testator w chwili sporządzania testamentu był of sound mind (odpowiada: poczytalności, w pełni władz umysłowych - sec. 57 t.p.c.). W pewnym uproszczeniu można pojęcia zdolności testamentowej i poczytalności traktować synonimicznie ${ }^{14}$. W doktrynie i orzecznictwie prawa spadkowego stanu Teksas przyjmuje się, że przesłanka zdolności testamentowej (poczytalności) spełniona będzie w szczególności, gdy testator spełnia następujące wymogi. Po pierwsze, posiada dostateczną zdolność umysłową pozwalającą na rozumienie zdarzenia polegającego na sporządzaniu testamentu, w którym bierze udział. Po drugie, posiada dostateczną zdolność umysłową pozwalającą na rozumienie skutków, jakie wywoła sporządzony testament. Po trzecie, posiada dostateczną zdolność umysłową pozwalającą na rozumienie charakteru oraz wielkości posiadanego mienia. Po czwarte, posiada dostateczną zdolność umysłową pozwalającą wiedzieć, kto jest jego krewnym (zwłaszcza dziedziczącym w trybie ustawowym) oraz jaki jest charakter przedmiotów, które mają zostać rozdysponowane w testamencie, a także wiedzieć, że krewni będą mogli wnosić skargi i inne środki

13 Ustawa z 1955 r. Texas Probate Code, obowiązująca od 1 stycznia 1956 r., ze zm. Zob. np. G. W. Beyer, Texas Probate Code, s. 42.

14 Por. np. Chambers v. Chambers, 542 S.W.2d 901, 906 (Civ. App.-Dallas 1976, no writ); G. S. Silverblatt, Texas Supplement To Accompany Wills, Trusts, and Estate Administration For The Paralegal (D. R. Hower, fith edition), wersja elektroniczna, s. 16. 
prawne względem sporządzonego testamentu. Po piąte, posiada dostateczną zdolność umysłową pozwalającą na rozumienie procesów biznesowych, w których zaangażowany jest jego majątek, $\mathrm{w}$ szczególności zdaje sobie sprawę $\mathrm{z}$ prowadzonych $\mathrm{w}$ majątku przedsięwzięć, które muszą zostać zakończone. Po szóste zaś, posiada dostateczną zdolność umysłową pozwalającą na dokonanie rozsądnej oceny podjętych przez siebie rozrządzeń, a zwłaszcza oczywistych relacji pomiędzy poszczególnymi elementami majątku, a także posiada dostateczną pamięć, by zapamiętać dokonane $\mathrm{w}$ testamencie rozrządzenia ${ }^{15}$.

Wskazane wyliczenie stanowi jedynie przykładowe okoliczności mogące być pomocne przy ocenie zdolności testamentowej testatora w stanie faktycznym zaistniałym w konkretnej sprawie. Istotą dokonywanej oceny jest każdorazowo zbadanie, czy testator miał dostateczne rozeznanie $\mathrm{w}$ zakresie podejmowanych przez siebie czynności. Będzie to szczególnie ważkie przy kwalifikowaniu zachowań dokonywanych przez osoby w bardzo podeszłym wieku ${ }^{16}$.

Dla określenia, czy w okolicznościach konkretnej sprawy spełniona została przesłanka zdolności testamentowej przydatna może być analiza orzecznictwa teksaskiego. Warto wskazać przynajmniej na dwie sprawy. W orzeczeniu Lowery $v$. Saunders ${ }^{17}$ sąd apelacyjny wskazał, że przy badaniu zdolności testamentowej należy brać pod uwagę stan umysłowy testatora dokładnie $z$ chwili sporządzania testamentu. Brak dostatecznej świadomości i rozeznania testatora odnośnie do podejmowanych czynności, który ma miejsce przed sporządzeniem testamentu lub po tym fakcie, może być ewentualnie

15 Por. np. orzeczenie Stephen v. Coleman, 533 S.W.2d 444 (Tex. Civ. App. — Fort Worth 1976, writ ref'd n.r.e.); orzeczenie Gillispie v. Reinhardt, 596 S.W.2d 558, 559 (Civ. App.-Beaumont 1980, no writ); orzeczenie Bettis v. Bettis, 518 S.W.2d 396, 397-398 (Civ. App.-Austin 1975, ref. n.r.e.); orzeczenie Jones v. LaFargue, 758 S.W.2d 320 (Tex. App.-Houston [14th Dist.] 1988, den.); G. W. Beyer, Texas Probate Code, s. 42.

${ }^{16}$ Zob. np. J. M. Young, Testamentary Capacity, z dnia 30.04.2008, opublikowane na portalu http://www.txprobatelitigation.com/basic_will_requirements (dostęp: 12.02.2017 r.).

17 Orzeczenie Lowery v. Saunders, 666 S.W.2d 226 (Tex. App.-San Antonio 1984, ref. n.r.e.). 
brany pod uwagę, ale jedynie w celu wykazania, że wskazany brak utrzymywał się przez dłuższy czas, a więc także w momencie, gdy sporządzany był testament ${ }^{18}$.

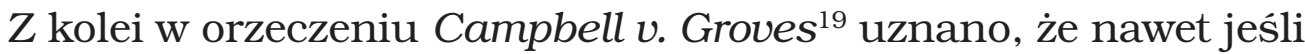
testator powoływał się na przypadki prześladowania, które nigdy w rzeczywistości nie miały miejsca, a ponadto doznawał halucynacji, to okoliczności takie nie są wystarczające, by uznać, że nie posiadał zdolności testamentowej w momencie sporządzania testamentu. Sąd apelacyjny stanął na stanowisku, że niektóre dziwne i osobliwe zachowania testatora nie muszą od razu oznaczać, że w chwili sporządzania testamentu testator nie posiada zdolności testamentowej. Wymagany jest w tym przypadku wyraźny dowód, że taka sytuacja rzeczywiście miała miejsce ${ }^{20}$.

\section{Przesłanka testamentary intent}

Wymóg spełnienia przesłanki woli testowania (testamentary intent) nie jest obowiązkiem przewidzianym przez ustawę i przepisy prawa stanowionego. Obowiązek ten wynika $z$ dorobku orzecznictwa (case law), mogącego w prawie spadkowym stanu Teksas stanowić źródło prawa. Zgodnie ze wskazanym dorobkiem orzeczniczym przyjmuje się, że wola testowania (animus testandi) nie wynika $z$ samego faktu tworzenia dokumentu testamentowego ani też $z$ nazwania dokumentu testamentem. Wynika ona $z$ chęci rozdysponowania swoim majątkiem na wypadek śmierci. Przy czym dyspozycja taka może być odwołana. Nie oznacza to jednak dowolności form przy dokonywaniu takiego rozdysponowania. Wola rozdysponowania majątkiem powinna zostać ujęta w dokumencie testamentowym²1.

18 Por. orzeczenie Lowery v. Saunders, op.cit.; zob. także G. S. Silverblatt, op.cit., s. 16.

19 Por. orzeczenie Campbell $v$. Groves, 774 S.W.2d 717 (Tex. App.-El Paso 1989, den.).

20 Por. orzeczenie Campbell $v$. Groves, op.cit.; zob. także G. S. Silverblatt, op.cit., s. 16.

21 Por. np. orzeczenie Hinson $v$. Hinson, 280 S.W.2d 731, 733 (Tex. 1955); zob. także S. R. Akers, op.cit., s. 4. 
W doktrynie wskazuje się z kolei, że dla wyrażenia woli testowania nie jest konieczne używanie ściśle określonych słów. Niemniej jednak użycie przez testatora zwrotów takich jak last will (ostatnia wola), testament (testament) czy my last will and desire (moja ostatnia wola i życzenie), mogą stanowić istotny argument wskazujący na fakt, że dany dokument w rzeczywistości jest testamentem. Co więcej przyjmuje się nawet, że nie jest niezbędne, by testator zdawał sobie sprawę, że dokument który tworzy, stanowi w sensie prawnym testament. Testator musi jednak jednocześnie zdawać sobie sprawę $z$ faktu, że sporządza dokument, za pomocą którego dokona rozdysponowania swoim majątkiem na wypadek smierci. Testamentu nie będzie także stanowić dokument, w którym zawarte są wyłącznie obietnice dotyczące przyszłego przekazania komuś darowizny, w szczególności jeśli miałaby ona nastąpić jeszcze za życia spadkodawcy ${ }^{22}$.

$Z$ uwagi na fakt, że kwestia dookreślenia przesłanki woli testatora stanowi w istocie wytwór judykatury amerykańskiej, zwłaszcza dorobku teksaskich sądów, odwołać się należy przynajmniej do kilku najistotniejszych orzeczeń.

W orzeczeniu In re Estate of Brown ${ }^{23}$ podkreślono, że przy określeniu, czy zgodnie $z$ wolą testatora sporządzony przez niego dokument może być uznany za testament, badaniu podlega kilka kwestii. Rozważyć należy niektóre $z$ nich. Po pierwsze, czy w dokumencie dokonano rozrządzenia składnikami majątkowymi testatora. Po drugie, czy dokument będzie wywoływał skutek dopiero po śmierci testatora (mortis causa). Po trzecie natomiast, czy z charakteru dokumentu wynika, że może być on swobodnie zmieniony lub odwołany przez testatora $\mathrm{w}$ dowolnym momencie. Jednocześnie $\mathrm{w}$ omawianym orzeczeniu podniesiono, że określony dokument może być w wyjątkowych okolicznościach uznany za testament, nawet jeśli wskazane uprzednio kryteria nie zostałyby spełnione. Mogłoby to mieć miejsce np. w sytuacji, gdyby dokument stanowił testament odwołujący poprzedni testament i nie wprowadzał żad-

${ }^{22}$ Zob. np. J. M. Young, Testamentary Capacity.

${ }^{23}$ Orzeczenie In re Estate of Brown, 507 S.W.2d 801, 803 (Civ. App.-Dallas 1974, ref. n.r.e.). 
nych rozrządzeń lub też stanowił testament powołujący określonego wykonawcę testamentu lub opiekuna ${ }^{24}$.

W innej sprawie, Thomasson $v$. Kirk ${ }^{25}$, teksaski sąd stanął na stanowisku, że niektóre określenia $z$ języka potocznego (przy odpowiedniej wykładni) mogą wskazywać na wolę testatora odnośnie do tego, iż sporządzony przez niego dokument stanowi w istocie testament. W okolicznościach stanu faktycznego analizowanej sprawy określenie my will and desire (w uproszczeniu: moja wola i życzenie) sąd zakwalifikował jako wyrazy wskazujące na wolę sporządzenia przez testatora testamentu, mimo że co do zasady, samodzielnie występujące słowo desire (w uproszczeniu: życzenie), rozważane poza użytym kontekstem, nie miałoby związku $z$ testamentem ${ }^{26}$.

Natomiast w orzeczeniu Huffman $v$. Huffman ${ }^{27}$ uznano, że wola testatora powinna wynikać ściśle $z$ użytych $\mathrm{w}$ treści testamentu słów. Nie powinno się jej rozszerzać zwłaszcza o kwestie, odnośnie do których testator nie wypowiedział się w treści testamentu, ale mógł je mieć na myśli ${ }^{28}$.

Interesujący stan faktyczny miał miejsce w sprawie In re Estate of Hendler $^{29}$. Ujmując całość sprawy w pewnym uproszczeniu, należałoby wskazać, że początkowo testator sporządził testament, na którego samym dole ostatniej strony uczynił nieco później własnoręczny dopisek. Oświadczył w nim, że obecnie jest rozwiedziony oraz że sporządzony przez niego wcześniej testament nadal obowiązuje. Sąd pierwszej instancji uznał wskazany dopisek jako ważny testament i odwołujący poprzedni testament, w związku z czym zarządził ponowne ogłoszenie testamentu. Ze stanowiskiem sądu pierwszej instancji nie zgodził się jednak sąd odwoławczy. Uznał,

24 Por. orzeczenie In re Estate of Brown, op.cit.; G. S. Silverblatt, op.cit., s. 15 .

25 Orzeczenie Thomasson v. Kirk, 859 S.W.2d 493 (Tex. App.-Houston [14th Dist.] 1993, den.).

26 Por. orzeczenie Thomasson v. Kirk, op.cit.; zob. także: G. S. Silverblatt, op.cit., s. 15 .

27 Por. orzeczenie Huffman v. Huffman, 329 S.W.2d 139 (Civ. App.-Fort Worth 1959), AFF’D, 161 Tex. 267, 339 S.W.2d 885, (1960).

28 Zob. także: G. S. Silverblatt, op.cit., s. 15.

29 Orzeczenie In re Estate of Hendler, 316 S.W.3d 703 (Tex. App.-Dallas 2010, no pet. h.). 
że wola testatora, wynikająca $z$ tak uczynionego dopisku, może być rozumiana na dwa sposoby. Po pierwsze, że jest to tylko pisemna wzmianka stwierdzająca stan faktyczny (rozwód) i podkreślająca, iż testament w dalszym ciągu pozostaje w mocy. Po drugie, że dopisek stanowił oświadczenie, iżtestator po rozwodzie ponownie przemyślał treść sporządzonego testamentu, ale nadal oddaje ona jego wolę w zakresie dokonanych rozrządzeń spadkowych. Oba sposoby wykładni zostały prze sąd uznane za uzasadnione. Zdaniem sądu odwoławczego, sąd pierwszej instancji nieco zbyt daleko rozszerzył wolę testatora o niezawarte $\mathrm{w}$ niej elementy, w związku $\mathrm{z}$ czym orzeczenie sądu pierwszej instancji było nietrafne ${ }^{30}$.

Warto choć krótko wspomnieć również o orzeczeniu In re Estate of Allen ${ }^{31}$. W trakcie trwającego postępowania spadkowego mającego na celu określenie ważności i treści testamentu, jeden z uczestników przekonał sąd pierwszej instancji, by uznać dopisane 13 wersetów za zmianę testamentu. Orzeczenie sądu pierwszej instancji zaskarżono, powołując się na to, że wskazane 13 wersetów nie zostało objętych wolą testamentową. Sąd apelacyjny ustalił, że wersety zawierały rozbudowaną listę ruchomości oraz wskazanie, że wykaz ten jest przeznaczony dla syna. Wykaz (zgodnie $z$ wymogami prawa dla ważności testamentu) został podpisany przez spadkodawcę przy asyście dwóch świadków. Jednakże wykaz nie został oznaczony słowami will (testament) lub codicil (w znacznym uproszczeniu testament dokonujący zmiany w poprzednim testamencie). Brak było także jakichkolwiek sformułowań, które wskazywałyby wyraźnie na wolę spadkodawcy rozdysponowania przedmiotami oznaczonymi w wykazie na wypadek śmierci. Sąd apelacyjny wskazał, że użycie słów statement (w stanie faktycznym analizowanej sprawy: oświadczenie) oraz zaznaczenie, że określone przedmioty są przeznaczone dla kogoś, nie oznacza, że wskazują one na dyspozycję na wypadek śmierci. Mogła ona nastąpić również za życia ${ }^{32}$.

30 Por. orzeczenie In re Estate of Hendler, op.cit.; G. W. Beyer, Texas Case Law Update, Dallas 2011, s. 1-2.

31 Orzeczenie In re Estate of Allen, 301 S.W.3d 923 (Tex. App.-Tyler 2009, pet. Denied).

${ }^{32}$ Por. orzeczenie In re Estate of Allen, op.cit.; G. W. Beyer, Texas Case Law, s. 2. 
110 Marcin Drewek

\section{Tzw. przesłanki formalne - formalities}

Kolejną z przesłanek ważności testamentu, właściwą dla prawa spadkowego stanu Teksas, można określić łącznie jako tzw. przesłankę formalną (formalities). Wskazane przesłanki są ściśle powiązane $z$ wymaganiami prawnymi, które są przypisane do poszczególnych form testamentu. W teksaskim prawie spadkowym dopuszczalne jest skorzystanie $\mathrm{z}$ rozmaitych form testamentów. $Z$ uwagi na fakt, że w praktyce obrotu zdecydowanie dominują dwie formy: pisemna odręczna (holograficzna) oraz pozostałe formy pisemne ( $\mathrm{w}$ tym w szczególności drukowana, maszynowa lub tworzona przez notariusza), przedstawienie warunków formalnych związanych z tymi dwiema formami uznać należy za wystarczające, z uwagi na cel niniejszego opracowania. Rozważone zostaną zatem dwie formy testamentu: holographic will (w uproszczeniu: testament holograficzny) oraz formal (statutory, attested) will (w uproszczeniu: testament formalny - sec. 59 t.p.c.).

\subsection{Holographic will}

W prawie spadkowym stanu Teksas jedną $z$ dopuszczalnych form sporządzenia testamentu jest testament własnoręczny - tzw. holographic (handwritten) will. Warunkiem ważności takiego testamentu jest, by został on w całości spisany własnoręcznie przez co do zasady testatora (sec. 59 t.p.c.). Konieczne jest także złożenie własnoręcznego podpisu na takim dokumencie przez testatora. Co istotne, testament nie musi być tworzony w asyście jakichkolwiek świadków. Może zostać sporządzony na dowolnym materiale. W treści testamentu holographic will nie jest dopuszczalne zamieszczanie jakichkolwiek słów spisanych na maszynie lub wydrukowanych. Ważne jest, by $z$ treści tak sporządzonego testamentu wynikała wola testatora do dokonania rozrządzeń na wypadek jego śmierci. Może to zostać dokonane w szczególności za pomocą użycia słów my last 
will and testament, które w praktyce obrotu prawnego stanu Teksas są uważane za wystarczające spełnienie wskazanego kryterium ${ }^{33}$.

Mimo że co do zasady, wymogi formalne dla sporządzenia omawianej formy testamentu nie nastręczają większych trudności w ich realizacji, skorzystanie $z$ niej może powodować pewne komplikacje w sądowym procesie dotyczącym zatwierdzenia testamentu. Wątpliwości powstawać będą zwłaszcza w zakresie wykładni. Przykładowo, jeśli w testamencie nie dokonano rozdysponowania całym majątkiem, pozostała część będzie podlegała ustawowym regułom dziedziczenia (tzw. intestacy). Ponadto jeśli poszczególne słowa zapisane w testamencie byłyby niewyraźne, sąd będzie uprawniony do dokonania odpowiedniej wykładni w celu ustalenia ich znaczenia. Warto również dodać, że jeśli $\mathrm{w}$ holographic will brak będzie odpowiednich zwrotów wymaganych przez teksaskie prawo spadkowe dla umożliwienia natychmiastowego zarządzania majątkiem przez wykonawcę testamentu na wypadek śmierci, wykonawca testamentu, przed rozpoczęciem działania, będzie musiał najpierw uzyskać odpowiednie zezwolenia sądu. W praktyce teksaskiego obrotu prawnego wydłuża to cały proces dziedziczenia oraz powoduje znaczny wzrost kosztów. Stąd ten rodzaj testamentu ten nie najczęściej wybieranym spośród możliwych rodzajów testowania ${ }^{34}$.

\subsection{Formal will}

Odnośnie do tzw. formal will (w uproszczeniu: testamentu formalnego) ustawodawca stanu Teksas nie przesądza, w jaki sposób testament ten powinien być spisany ani też za pomocą czego miałby zostać spisany. Niezbędnym elementem jest jednak to, by testament taki został podpisany przez testatora. Wobec braku dostatecznego wyjaśnienia kwestii podpisu w ustawie t.p.c., doktryna przyjmuje, że podpis należy rozumieć jako jakikolwiek symbol, wymyślony

${ }^{33}$ Zob. np. N. C. Koehler, op.cit. s. 6; E. Stoebner, Ten Checkpoints When Probating A Will, Atricles of Harrell, Stoebner \& Russell, P.C., http://www. templelawoffice.com/News-Articles/ (dostęp: 12.02.2017 r.), s. 4.

${ }^{34}$ Zob. np. N. C. Koehler, op.cit., s. 6. 
samodzielnie lub zainspirowany, za pomocą którego zaprezentowany zostaje zamiar poświadczenia autentyczności danego pisma. W związku z tym przyjmuje się, że wymogi te zostają spełnione także poprzez uczynienie inicjałów, znaków czy pseudonimów. Możliwe jest także złożenie przez upoważnioną osobę podpisu w imieniu testatora. Konieczne jest jednakże, by podpis został złożony na polecenie testatora oraz w jego obecności. W pewnych sytuacjach podpis może zostać także złożony przez notariusza, nawet w razie braku osobistej obecności testatora, jeśli złożeniu podpisu towarzyszy świadek, obecność testatora zaś nie jest fizycznie możliwa. Warto także dodać, że przepisy prawa spadkowego stanu Teksas nie precyzują, w którym miejscu testamentu podpis powinien się znajdować. W wyjątkowych sytuacjach podpis może zostać złożony nawet na osobnym dokumencie (affidavit), z którego będzie wynikać potwierdzenie autentyczności testamentu oraz fakt, że wolą testatora było, by dokument ten był uznany za jego testament ${ }^{35}$.

Odnośnie do kwestii podpisu warto przywołać orzeczenie Thomason v. Gwinn ${ }^{36}$. W orzeczeniu tym sąd stanął na stanowisku, że w niektórych, wyjątkowych okolicznościach podpis testatora może zostać nawet złożony przy pomocy maszyny do pisania lub przy użyciu klawiatury. $Z$ kolei w sprawie Burton v. Bell ${ }^{37}$ podkreślono, że nie jest istotne, w którym miejscu na dokumencie testator złożył swój podpis. Ważne jest jedynie, by podpis został objęty wolą testatora, jako mający być dołączony do testamentu. W innym orzeczeniu, Anderson v. Dubel ${ }^{38}$, sąd przyjął, że uczynienie przez testatora znaku, który w jego zamiarze i zgodnie $z$ jego wolą miał

35 Zob. np. orzeczenie Lawson v. Dawson's Estate, 53 S.W. 64 (Tex. Civ. App. - 1899, writ ref'd); zob. także G. W. Beyer, Texas Probate Code, s. 44-45; tenże, Avoid Being a Defendant: Estate Planning Malpractice and Ethical Concerns, "St. Mary's Journal on Legal Malpractice \& Ethics" 2015, Vol. 5 (224), s. 247; E. Stoebner, op.cit., s. 3; J. M. Young, Basic requisites for a valid will in Texas, $\mathrm{z}$ dnia 18.03.2008, opublikowane na portalu http://www.txprobatelitigation. com/basic_will_requirements/(dostęp: 12.02.2017 r.).

${ }^{36}$ Por. orzeczenie Thomason v. Gwinn, 184 S.W2d 542 (Civ. App.-Amarillo 1944, ref.).

37 Por. oreczenie Burton v. Bell, 380 S.W.2d 561, 568-569 (Tex. 1964).

38 Por. orzeczeni Anderson v. Dubel, 580 S.W.2d 404, 409 (Civ. App.-San Antonio 1979, ref. n.r.e.). 
stanowić podpis testamentu, jest wystarczający dla uznania, że testament jest ważny, o ile testator nie był w stanie podpisać się własnym imieniem ${ }^{39}$.

Dla ważności testamentu formalnego, zgodnie z prawem spadkowym Stanu Teksas, niezbędne jest także, by testament został sporządzony przy asyście odpowiedniej liczby świadków (sec. 59 t.p.c.). Co do zasady wymagane jest, by było to dwóch świadków. Świadek musi mieć ukończone minimum 14 lat. Istnieje ponadto wymóg, by świadkowie byli wiarygodni, tzn. zdolni do składania zeznań przed sądem zgodnie $z$ zasadami postępowania dowodowego. Wiarygodności świadka nie podważa zasadniczo sam fakt bycia jednocześnie świadkiem i wykonawcą testamentu, który się poświadcza, lub też urzędnikiem czy też członkiem określonej instytucji religijnej lub charytatywnej, która w związku z treścią testamentu ma stać się beneficjentem rozrządzeń testamentowych ${ }^{40}$.

Wskazany przykład odnoszący się do wymogów stawianych świadkom testamentowym stanowi jednak wyjątek od ogólnej zasady, zgodnie $\mathrm{z}$ którą podmioty wymienione $\mathrm{w}$ testamencie jako beneficjenci nie powinni być jednocześnie świadkami sporządzania takiego testamentu. Zgodnie $z$ prawem spadkowym stanu Teksas w takim przypadku określone powołanie, zapis lub polecenie będzie nieważne. W tym zakresie mogą istnieć pewne wyjątki. Ważność i skuteczność poszczególnych rozrządzeń testamentowych może być zachowana poprzez potwierdzenie faktu ich zamieszczenia $\mathrm{w}$ testamencie przez osoby trzecie, które są wiarygodne i jednocześnie nie są beneficjentami (sec. 62 t.p.c.). Inny wyjątek może stanowić sytuacja, w której świadek sporządzenia testamentu jest jednocześnie jego beneficjentem, ale w przypadku gdyby testament nie został sporządzony i tak dziedziczyłby on zgodnie $z$ treścią przepisów ustawy. Wówczas osoba taka (będące jednocześnie świadkiem i beneficjentem) może uzyskać prawa podmiotowe na podstawie testamentu, jednak tylko w takim zakresie, w jakim uzyskałaby

39 Szerzej na ten temat zob. G. S. Silverblatt, op.cit., s. 17.

40 Por. np. orzeczenie Moos v. First State Bank, 60 S.W.2d 888 (Tex. Civ. App. 1933, writ dism'd w.o.j.); zob. także: G. W. Beyer, Texas Probate Code, s. 45; G. S. Silverblatt, op.cit., s. 17. 
prawa podmiotowe na mocy ustawy i jednocześnie jedynie do wysokości wskazanej w treści testamentu (sec. 61 t.p.c.) ${ }^{41}$.

W doktrynie i orzecznictwie prawa spadkowego stanu Teksas przyjmuje się ponadto, że świadkowie nie muszą być koniecznie świadomi, że są świadkami sporządzanego testamentu. Świadkowie muszą jedynie mieć wolę potwierdzenia prawdziwości dokumentu jako dokumentu sporządzonego przez testatora. Nie muszą także wiedzieć, że dokument taki stanowi w istocie testament, choć wiedza taka jest bardzo pożądana. Pożądane jest również, by przed sądem, w trakcie toczącego się postępowania spadkowego, świadkowie byli w stanie stwierdzić, czy okazana im treść dokumentu pokrywa się $z$ treścią sporządzonego przez testatora testamentu ${ }^{42}$. Co więcej, w przeciwieństwie do podpisu testatora, podpisy świadków muszą zostać wyrażone za pomocą ich imion oraz muszą zostać sporządzone własnoręcznie. Nie jest przy tym dopuszczalne posługiwanie się samymi znakami zastępującymi imiona. Nie jest również możliwe sporządzenie podpisu przez pełnomocnika. Ponadto, zgodnie $z$ wymogami prawa, świadkowie powinni złożyć swoje podpisy na końcu testamentu (sec. 59 (a) t.p.c.). Należy jednakże podkreślić, że judykatura teksaska nie kładzie zbyt dużego nacisku na ścisłe przestrzeganie tego wymogu ${ }^{43}$.

Kolejny wymóg stanowi konieczność poświadczenia przez świadków sporządzenia testamentu w obecności testatora. Kwestia ta nastręcza w teksaskim prawie spadkowym wielu wątpliwości. Orzecznictwo zasadniczo wykłada pojeccie tzw. in the presence of the testator (w uproszczeniu: w obecności testatora) jako obecności świadomej, tzn. że testator (za wyjątkiem sytuacji, kiedy jest on osobą niewidomą) jest w stanie widzieć świadków ze swoje aktualnej pozycji przez cały czas (lub przez większość czasu) lub też przy niewielkiej zmianie pozycji, w której się znajduje. Istotne jest przy

${ }^{41}$ Zob. np. G. W. Beyer, Avoid Being a Defendant, s. 248; N. C. Koehler, op.cit., s. 6; G. S. Silverblatt, op.cit., s. 17.

42 Por. orzeczenie Davis v. Davis, 45 S.W.2d 240 (Tex. Civ. App. - Beaumont 1931, no writ); zob. także: G. W. Beyer, Texas Probate Code, s. 45; E. Stoebner, op.cit., s. 3.

${ }^{43}$ Por. orzeczenie Fowler $v$. Stagner, 55 Tex. 393 (1881); zob. także: G. W. Beyer, Texas Probate Code, s. 45; G. S. Silverblatt, op.cit., s. 17. 
tym, by mógłby dokonać zmian bez pomocy. Warto także dodać, że prawo spadkowe stanu Teksas, w przeciwieństwie do wielu innych stanowych ustawodawstw amerykańskich, nie wymaga ani obecności obu świadków naraz, ani też by testator podpisał testament w obecności świadków. Mimo to zaleca się, by podpisy świadków zostały złożone we wzajemnej obecności, choć i ten wymóg nie jest niezbędny $^{44}$.

Odnosząc się do kwestii kolejności podpisów, warto wskazać, że chociaż zgodnie $z$ ogólnym zaleceniem testator powinien złożyć swój podpis przed podpisami składanymi przez świadków, to jednak nakaz ten nie jest zbyt rygorystycznie wykładany przez teksaskie sądy. Zamiast tego judykatura dokonuje tzw. postrzegania transakcyjnego. Oznacza to, że jeśli sporządzanie testamentu i jego poświadczenie przez świadków następować będzie w tym samym czasie i miejscu, a także stanowi część dokonywanej czynności prawnej (sporządzania testamentu), to bez znaczenia pozostaje fakt, iż podpis świadka został złożony przed podpisem testatora ${ }^{45}$.

Przedstawienie analizowanej kwestii dotyczącej przesłanek ważności testamentów formalnych wymaga dodatkowo uzupełnienia o krótkie omówienie postępowania dowodowego. Ściślej rzecz ujmując, chodzi tutaj o instytucje prawne przewidziane przez prawo spadkowe stanu Teksas dla ułatwienia dowodzenia ważności testamentu. Należałoby wskazać w tym miejscu zasadniczo na dwa tinstrumenty: tzw. self-proving affidavit (w uproszczeniu: oświadczenie, które zastępuje konieczność dowodzenia) oraz tzw. attestation clause (w uproszczeniu: klauzula poświadczająca).

Фświadczenie self-proving affidavit przewidziane zostało przez ustawodawcę teksaskiego w ustawie t.p.c. Jego sporządzenie nie jest konieczne do zachowania ważności testamentu. Może ono zostać sporządzone na osobnym dokumencie lub treści testamentu jako

${ }^{44}$ Por. orzeczenie Nichols v. Rowan, 442 S.W.2d 21 (Tex. Civ. App. - San Antonio 1967, writ ref'd n.r.e.); zob. także G. W. Beyer, Texas Probate Code, s. 45; N. C. Koehler, op.cit., s. 6; E. Stoebner, op.cit., s. 3.

45 Por. np. orzeczenia: James v. Haupt, 573 S.W.2d 285, 289 (Tex. Civ. App. - Tyler 1978, writ ref'd n.r.e.) oraz In re Estate of Pruitt, 249 S.W.3d 654 (Tex. App.-Fort Worth 2008, no pet.); zob. także G. W. Beyer, Texas Probate Code, s. 45. 
osobne postanowienie. W praktyce teksaskiego obrotu prawnego zdecydowana większość testatorów dba o to, by stosowne oświadczenie self-proving affidavit zostało sporządzone. Pozwala ono bowiem na to, by sąd przyjął takie oświadczenie jako ekwiwalent dla zeznań świadków, które potwierdzałyby, że byli oni świadkami sporządzenia testamentu. Self-proving affidavit stanowi bardzo silny dowód w formie pisemnej. Sądy posiadają uprawnienie, by oprzeć się wyłącznie na treści tego oświadczenia i bez wzywania jakichkolwiek świadków testamentowych od razu wydać orzeczenia kończące postępowanie spadkowe. Stąd też pochodzi określenie self-proving (w uproszczeniu: zastępujące konieczność dowodzenia). Pozwala to na znaczną oszczędność czasu i pieniędzy w trakcie sądowego postępowania spadkowego ${ }^{46}$.

Niekiedy może się jednak okazać, że omawiane oświadczenia \$elf-proving affidavit będzie nieskuteczne. Może to mieć miejsce w szczególności w sytuacji, gdy testator lub świadkowie zapomną podpisać oświadczenie. W praktyce obrotu prawnego stanu Teksas bardzo często dochodzi do sytuacji, w której testator i świadkowi podpiszą oświadczenie self-proving affidavit, natomiast zapomną złożyć swoje podpisy pod treścią testamentu. Pojawia się wówczas pytanie o ważność testamentu. Zagadnienie to stanowiło istotny problem dla doktryny i judykatury. Początkowo orzecznictwo przyjmowało, że w takiej sytuacji testament jest nieważny. Ustawodawca stanu Teksas uznał jednak ostatecznie, że sytuacja taka nie odpowiada potrzebom obrotu prawnego i wprowadził do ustawy t.p.c. zapis, zgodnie $z$ którym dopuszczalna jest konwersja podpisu złożonego na oświadczeniu i potraktowanie go jako podpisu złożonego na testamencie. Dzięki takiemu zabiegowi testament pozostaje ważny, jednak oświadczenie self-proving affidavit staje się wówczas bezskuteczne. W takiej sytuacji niezbędne jest powołanie przez sąd spadkowy świadków na okoliczność oceny, czy testament faktycznie jest testamentem sporządzonym przez testatora ${ }^{47}$.

46 Szerzej na ten temat zob. np. G. W. Beyer, Texas Probate Code, s. 45.

47 Szerzej na ten temat por. orzeczenie Boren v. Boren, 402 S.W.2d 728 (Tex. 1966); zob. także: G. W. Beyer, Texas Probate Code, s. 45; tenże, Avoid Being a Defendant, s. 248-249. 
Z kolei klauzula attestation clause przedstawia nieco inną wartość dowodową. Jest ona zazwyczaj zamieszczana w tym samym dokumencie co testament, jako postanowienie dodatkowe. Umieszcza się ją poniżej podpisu testatora, ale jednocześnie powyżej podpisów złożonych przez świadków. Celem klauzuli attestation clause jest potwierdzenie, że testament został sporządzony w sposób ważny. W szczególności warto podkreślić, że świadkowie przy pomocy wskazanej klauzuli potwierdzają pisemnie, że testament został sporządzony w ich obecności, testator był w momencie jego sporządzania poczytalny oraz miał ukończone 18 lat. Wskazana klauzula stanowi bardzo silny środek dowodowy pozwalający na ustalenie przy jego pomocy faktów w nim zawartych. Stosowana jest zwłaszcza na wypadek śmierci świadków, zaniku pamięci lub też w przypadku wystąpienia innych okoliczności, które mogłyby podważać ważność sporządzonego testamentu. W przeciwieństwie jednak do oświadczenia self-proving affidavit, niezbędne jest wezwanie świadków celem przeprowadzenia postępowania dowodowego, a dopiero gdyby to napotykało na trudności, możliwe jest zastosowanie omawianej klauzuli attestation clause ${ }^{48}$.

\section{Inne okoliczności mogące wpływać}

\section{na ważność testamentu}

Wpływ na ważność testamentu, zgodnie $z$ prawem spadkowym stanu Teksas, mogą wywierać także inne (niż wskazane uprzednio) okoliczności. W szczególności będzie tutaj mowa o trzech kwestiach. Po pierwsze: errors and mistakes (odpowiada pojęciu omyłki oraz błędy), po drugie, fraud (odpowiada pojęciu oszustwa), po trzecie zaś, undue influence (rodzaj bezprawnego nacisku osób trzecich). Ze względu na ramy objętościowe niniejszego opracowania, zaprezentowane zostaną jedynie wybrane przykłady odnoszące się do wskazanych kwestii ${ }^{49}$.

48 Szerzej na ten temat zob. np. E. Stoebner, op.cit., s. 3.

49 Szerzej na temat możliwych omyłek i błędów oraz ich różnorodnego wpływu na ważność testamentu zob. np. G. W. Beyer, Avoid Being a Defendant, s. 228-273. 
Bardzo znaczna część omyłek oraz błędów powstaje w związku Z niedostatecznie uważnym przeczytaniem dokumentu mającego stanowić testament. Dotyczy to zwłaszcza okresu bezpośrednio poprzedzającego sporządzenie testamentu. W praktyce obrotu prawnego stanu Teksas dość powszechnie zdarza się, że dokumenty podpisywane są w pośpiechu, nie zawsze też sporządzane są w asyście osoby znającej się na kwestiach prawnych. Bardzo często prowadzi to do drobnych błędów mogących wpływ na późniejsze sądowe postępowanie spadkowe. Przykładowo można wskazać na przejęzyczenia w imionach i nazwiskach osób mających uzyskać określone prawa podmiotowe na podstawie testamentu ${ }^{50}$. W orzeczeniu Scandurro $v$. Beto $^{51}$ wskazano jednak, że nie każdy błąd może być dostateczną podstawą do stwierdzenia nieważności testamentu. Co do zasady w grę może wchodzić jedynie taki błąd, który dotyczy dokumentu testamentowego lub jego treści.

Oszustwo (w pewnym zakresie także podstęp) może być traktowane jako inny przykład okoliczności, które mogą warunkować stwierdzenie wadliwości testamentu. W doktrynie prawa spadkowego stanu Teksas przyjmuje się, co do zasady, że oszustwo stanowić może zachowanie przebiegłe i oszukańcze, skutkujące szkodą w sferze prawnej innego podmiotu ${ }^{52}$. W orzeczeniu Guest $v$. Guest ${ }^{53}$ sąd stwierdził, że oszustwo stanowi także sytuacja, w której fałszywie zaprezentowano pewne fakty w celu nakłonienia odbiorcy do określonego zachowania, a następnie osoba ta podejmowała określone działania w oparciu o uzyskane błędne informacje i doznała w ten sposób szkody.

Do kwestii groźby oraz bezprawnego nacisku osób trzecich nawiązuje $z$ kolei sprawa In Whatley $v$. McKanna ${ }^{54}$. Wskazano w niej, że poprzez groźbę lub bezprawny nacisk można rozumieć wywieranie

50 Zob. np. G. W. Beyer, Avoid Being a Defendant, s. 238.

51 Por. orzeczenie Scandurro v. Beto, 234 S.W.2d 695 (Civ. App.-Waco 1950, no writ); G. S. Silverblatt, op.cit., s. 18.

52 Zob. np. G. S. Silverblatt, op.cit., s. 18.

53 Por. orzeczenie Guest v. Guest, 235 S.W.2d 710, 713 (Civ. App.-Fort Worth 1950, ref. n.r.e.); zob. także: G. S. Silverblatt, op.cit., s. 18.

54 Orzeczenie In Whatley v. McKanna, 207 S.W.2d 645 (Civ. App.-Eastland 1948, ref. n.r.e.). 
wpływu na testatora (np. poprzez wywoływanie strachu, pragnienia uzyskania spokoju, a nawet poprzez oddziaływanie za pomocą emocji, którym testator nie jest w stanie się oprzeć) w celu skłonienia go do zachowań przeciwko jego rzeczywistej woli. W celu wykazania omawianego undue influence (groźby lub innego bezprawnego nacisku) w toku postępowania niezbędne jest wykazanie kilku kwestii. Należą do nich zwłaszcza: po pierwsze, istnienie i zwiększanie wpływu na testatora, po drugie, efektywne wykorzystanie takiego wpływu wystarczające do zawładnięcia wolą testatora w czasie sporządzania testamentu, natomiast po trzecie, testament musi zostać sporządzony w sposób sprzeczny $z$ wolą testatora, która istniałaby, gdyby nie wpływano na testatora. $Z$ uwagi jednak na fakt, że każda osoba poczytalna może sporządzić testament wedle swojej woli, niezbędne jest wyraźne wykazanie związku przyczynowego pomiędzy undue influence a treścią sporządzonego testamentu ${ }^{55}$.

\section{Konkluzja}

W konkluzji należałoby wskazać, że przesłanki warunkujące ważność testamentu w prawie amerykańskim, zwłaszcza prawie spadkowym stanu Teksas, są w znacznym stopniu zbliżone do analogicznych przesłanek występujących na gruncie polskiego sytemu prawnego. Przykładowo można nadmienić, że przesłanki legal capacity i testamentary capacity, mimo pewnych różnic, odpowiadają paralelnej polskiej przesłance zdolności testowania (art. 944 k. c.). Ponadto główna zasada wykładni przesłanek, a więc wykładni na korzyść ważności testamentu (favor testamenti), również występuje w obu wskazanych systemach prawnych. Jak się więc wydaje, nie byłoby wykluczone stwierdzenie, że podstawowe kwestie odnoszące się do przesłanek warunkujących ważność testamentu w prawie teksaskim oraz polskim są zasadniczo zbliżone.

Konkluzja ta może być przydatna w sytuacji, gdy konieczne będzie dokonanie oceny ważności testamentu jednocześnie $z$ punktu

55 Por. orzeczenie In Whatley v. McKanna, op.cit.; zob. także: G. S. Silverblatt, op.cit., s. 18. 
widzenia prawa teksaskiego i polskiego. $Z$ uwagi na pogłębiającą się globalizację, sytuacje takie coraz częściej mogą mieć miejsce. W doktrynie prawa amerykańskiego podkreśla się przy tym wyraźnie, że w przypadku, gdy majątek spadkowy znajduje się na terenie kilku jurysdykcji, konieczne może okazać się ocenienie ważności testamentu w oparciu o kilka praw właściwych naraz ${ }^{56}$. Wskazane podobieństwa pomiędzy przesłankami ważności testamentu mogą więc zachęcać do skorzystania $z$ amerykańskiego dorobku prawnego dla tworzenia coraz lepszych rozwiązań na gruncie polskiego prawa spadkowego.

\section{STRESZCZENIE}

Kwestia ważności testamentu w prawie amerykańskim na przykładzie prawa stanu Teksas

Celem niniejszego opracowania jest zaprezentowanie podstawowych kwestii jurydycznych odnoszących się do przesłanek ważności testamentu, obowiązujących na gruncie prawa amerykańskiego, konkretnie zaś w prawie spadkowym stanu Teksas. Całość rozważań poprzedzona została wyjaśnieniem podstawowych zasad odnoszących się do kwestii oceny ważności testamentu. Omówione zostały szczegółowo cztery przesłanki podstawowe: legal capacity, testamentary capacity, testamentary intent oraz tzw. formalities (przesłanka o charakterze złożonym). Ponadto wspomniane zostały dodatkowe przesłanki warunkujące ważność testamentu, takie jak np. undue influence. Poza regulacjami prawnymi omówione zostały także aktualne poglądy doktrynalne oraz orzecznictwo, co jest szczególnie istotne, zważywszy na katalog źródeł prawa systemów prawnych common law. Wskazane opracowanie prowadzi do konkluzji, że katalog przesłanek warunkujących ważność testamentu w prawie spadkowym stanu Teksas ma wiele punktów zbieżnych $z$ regulacjami przyjętymi w polskim systemie prawnym. Można by wręcz poczynić konstatację, że dostrzegalne zdaje się w tym zakresie więcej podobieństw niż różnic.

${ }^{56}$ Szerzej na ten temat zob. np. R. C. Lawrence, E. S. Rizzo, Basic Conflict of Laws Principles, http://apps.americanbar.org/abastore/products/books / abstracts/5430661_chap1_abs.pdf (dostęp: 12.02.2017 r.), s. 13-14. 
Słowa kluczowe: prawo spadkowe; prawo amerykańskie; prawo teksaskie; przesłanki ważności testamentu

\title{
SUMMARY
}

\author{
Requirements of a valid will in the American law \\ based on the example of the Texas law
}

The aim of this article is to present the basic legal issues regarding requirements of a valid will, that are in force under the American law, and in particular in Succession Law of the Texas State. The substance consideration will be preceded by clarifying the key principles referring to the issue of judgment of the will validity. Also the detailed elaboration on four primary requirements: legal capacity, testamentary capacity, testamentary intent and so-called formalities (requirement of a complex nature) was made. Moreover there were mentioned additional requirements, which are indispensable for a will's validity, for instance undue influence. Except for the legal regulations, some regards were made on current scholarship acquis as well as on case law, which is substantial when referring issues concerning common law legal system. The above-mentioned regards might be concluded, that the catalogue of the legal requirements of a valid will in the Texas Succession Law has a number of points of convergence with legal requirements in the field of the Polish Law. Furthermore it might be even indicated, that in this scope may be noticed more similarities than distinctions.

Keywords: succession law; American law; Texas law; requirements of a valid will

\section{BIBLIOGRAFIA}

Akers S. R., Wills Road Map: Practical Considerations in Will Drafting, Austin 2012.

Beyer G. W., Texas Probate Code with Commentary, Lubbock 2013.

Beyer G. W., Texas Case Law Update, Dallas 2011.

Beyer G. W., Avoid Being a Defendant: Estate Planning Malpractice and Ethical Concerns, "St. Mary's Journal on Legal Malpractice \& Ethics" 2015, vol. 5 (224).

Koehler N. C. (The Texas Young Lawyers Association Texas Probate Passport Team), Texas Probate Passport, Austin 2011. 
Lawrence R. C., Rizzo E. S., Basic Conflict of Laws Principles, http://apps. americanbar.org/abastore/products/books/abstracts/5430661_chap1_ abs.pdf (dostęp: 12.02.2017 r.).

Pargaman W. D., The Story of the Texas Estates Code, Austin 2014.

Silverblatt G. S., Texas Supplement To Accompany Wills, Trusts, and Estate Administration For The Paralegal (D. R. Hower, fith edition), wersja elektroniczna.

Stoebner E., Ten Checkpoints When Probating A Will, Atricles of Harrell, Stoebner \& Russell, P.C., http://www.templelawoffice.com/NewsArticles/ (dostęp: 12.02.2017 r.).

Young J. M., Testamentary Capacity, $\mathrm{z}$ dnia 30.04.2008, opublikowane na portalu http://www.txprobatelitigation.com/basic_will_requirements (dostęp: 12.02.2017 r.).

Young J. M., Basic requisites for a valid will in Texas, $\mathrm{z}$ dnia 18.03.2008, opublikowane na portalu http://www.txprobatelitigation.com/basic_ will_requirements / (dostęp: 12.02.2017 r.). 